\title{
Prevalence of human papillomavirus (HPV) in oral cavity and oropharynx
}

Therezita Peixoto Patury Galvão Castro ${ }^{1}$, Ivo
Bussoloti Filbo

\section{Resumo / Summary}

\begin{abstract}
$\mathrm{T}$ he prevalence of human papillomavirus (HPV) in the oral cavity and oropharynx has not yet been as well studied as its infection of the vaginal tract. However, new study are emerge after the development of molecular biology techniques. The objective of this study is to show the prevalence of HPV in the oral cavity and the oropharynx. An ample bibliographic review was done showing a prevalence of HPV 6, 11 in a normal oral mucous membrane (latent infection). In oral benign lesions associated with HPV, a prevalence of HPV 6 and 11 was observed in squamous cell papilloma (SCP) and condylomas acuminatum, while HPV 2 and 57 were more prevalent in verruca vulgaris lesions. As for focal epithelial hyperplasia (FEH) and oral cancer, especially squamous cell carcinoma (SCC), the prevalence was of HPV 13 and 32, and HPV 16, respectively. The last findings are, nonetheless, controversial. The last findings are, nonetheless, controversial. Showed also discrepancy result the prevalence of human papillomavírus (HPV) in normal oral mucous (latent infection) and in oral cancer, however evidenced confirmatory result in oral benign lesions associated with virus.
\end{abstract}




\section{INTRODUCTION}

HPV is the acronym used to identify the human papillomavirus, responsible for the condiloma acuminata (from the Greek term kondilus = round tumor and the Latin term acuminare $=$ make it pointed $)^{1}$.

Human papillomavirus belong to a large family of viruses, the papovaviridae. They are small (about $55 \mathrm{~nm}$ in diameter) and epitheliotropic. Their genome is made up of 7,200 - 8,000 base pairs with molecular weights of $5.2 \mathrm{x}$ 106 Daltons. They have a capsule with 72 capsomeres of icosahedral structures, without lipoprotein envelope, and in a single circular double DNA molecule $e^{2-5}$.

Human papillomavirus infections and its spread occur all over the world. HPV infect the skin and mucosas and might induce the formation of both benign and malignant tumors6. The infection starts when the virus penetrates the new host, through micro-injuries. The development of this incubation phase into active expression depends on three factors: cell permeability, virus type and the host's immune status? ${ }^{7}$.

HPV prevalence in the normal oral mucosa (latent infection) and its relation to oral cancer have generated conflicting opinions. The discrepancy observed is mainly attributed to a variation in the sensitivity of the methods employed and epidemiologic factors related to the group of patients examined ${ }^{8}$.

The goal of the present study is to carry out a bibliographic review on the prevalence of human papillomavirus in the oral cavity and oropharynx through HPV detection methods, immunohistochemistry, in situ hybridization, Southern blot hybridization and polymerase chain reaction, checking the HPV types prevalent in the normal oral mucosa (latent infection), in benign oral and oropharynx lesions (squamous cells papilloma, condiloma acuminata, common wart and focal epithelial hyperplasia), and in oral cancer.

\section{LITERATURE REVIEW}

\section{HPV detection methods}

The diagnosis of human papillomavirus in the oral mucosa may be suspected when one inspects the lesion, and also through cytology and biopsy. The cytological aspect of the HPV infection is characterized by:

A. Major criteria: classic coilocytes, perinuclear cytoplasmic halos and nuclear dysplasia.

B. Minor criteria: dysceratocytes, atypical immature metaplasia, macrocyte and binucleation. This method bears limited sensitivity and does not type the HPV ${ }^{9,10}$.

The methods used to detect the HPV DNA in lesions vary broadly as far as their sensitivity and specificity are concerned ${ }^{11}$. These are further broken down in three categories:
Low Sensitivity: immunohistochemistry and in situ hybridization - because they only detect the virus when it is present in more than 10 copies of the viral DNA per cell.

Moderate Sensitivity: Southern blot, dot blot and reverse dot hybridizations, because they only detect the virus when present in 1 to 10 copies of the viral DNA per cell; and the High Sensitivity: PCR, because it detects the virus in less than 1 copy of the viral DNA per cell ${ }^{12}$.

Immunohistochemistry may detect the protein coat of HPV viral particles which are present in the lesions seen under light microscopy in paraffin bearing material or in cytological preparations, and in these cases, polyclonal antibodies are used against different types of HPV specific antigens. This technique is hampered by the limited availability of antibodies against specific types of HPV, since the virus does not replicate in vitro. Commercially available antibodies are created against bovina papillomavirus capsule antigens, with an HPV crossed reaction ${ }^{13}$.

Hybridization tests are currently the methods of choice to detect HPV DNA or RNA in smears or tissue samples. They are made directly or after DNA and RNA amplification through PCR. The basic principle behind these hybridization techniques is the double formation between the DNA single strand, RNA molecules or cloned HPV types, denaturated DNA derivatives and viral nucleic acid molecules present in the cell, which represents the hybridization test target ${ }^{10}$.

The Southern blot hybridization is used in order to detect the HPV DNA from biopsies and is considered the "gold standard" to detect HPV genome. It is a sensitive and highly specific test, thus proving to be a valuable research tool, however it has no application in clinical routine tests because it takes longer and it requires harder work ${ }^{10}$.

Another recently developed hybridization method is the hybrid capture (HCA), which does not distinguish among the specific HPV types; and their applicability as a research method is limited, however it may represent a good test for routine clinical use ${ }^{10}$.

Polymerase Chain Reaction (PCR) is a technique that has revolutionized virology, because of its extremely high sensitivity ${ }^{5}$. It is characterized by the amplification of minute amounts of target DNA sequences in many million times. It is a cyclic thermal process that includes three stages: denaturation, in which the double DNA strand is separated in single strains; coupling, in which the primers couple specifically with their complementary single strand target-DNA sequences; and finally, the primer extension, in which a thermostable DNA polymerase generates DNA "offspring" strands which cross the region between two primers. From then on, recently generated double strands serve as models for a subsequent PCR cycle. The primers may be: type-specific primers, which detect a simple type of HPV, or the consensus primers (also called general or 
generic), which detect a whole array of different HPV types in a single reaction ${ }^{14}$.

PCR detection of HPV is usually carried out through one of the consensus primers, the MY09-MY11 or the GP5/GP6 $6^{10,15}$. Currently, PCR allows for a more in depth assessment of epidemiologic data, including the prevalence of latent of subclinical infections. However, it bears the following disadvantages: amplification of minute amounts of contaminating HPV DNA, which may lead to falsepositive results. Each method is limited by its sensitivity, specificity, its practice, cost and its commercial availability. It is important and fundamental to assess the efficacy of different HPV detection techniques, in order to establish HPV etiology in oral lesions ${ }^{10,16}$.

\section{Human papillomavirus prevalence in the oral cavity and oropharynx}

HPV prevalence in the oral cavity and oropharynx is uncertain. Studies have shown dubious results, assessing a small number of patients and identifying some of the many HPV types found in mucosal lesions ${ }^{17}$.

So far, over 100 types of HPV have been identified18,19. Of these, 25 types have been associated to oral lesions (HPV-1, 2, 3, 4, 6, 7, 10, 11, 13, 16, 18, 31, $32,33,35,40,45,52,55,57,58,59,69,72$ and 73$)^{20}$.

In order to explain the HPV infection relationship with many oral lesions, it is important to investigate HPV prevalence in the normal oral mucosa.

\section{Human papillomavirus prevalence in normal oral mu- cosa}

Papillomavirus in normal oral mucosa must be investigated throughout studies on oral cavity HPV infection natural history. Its prevalence in the normal oral mucosa is controversial ${ }^{21}$.

In the normal oral mucosa we have seen a great variation in HPV rates detected, from $22 \%$ to $60 \%{ }^{17}$; from $0 \%$ all the way to $81.1 \%$ in studies using different methods, and with a limited number of individuals, and this seems to depend on the population studied and the choice of method $^{16,21}$. It has been suggested that HPV prevalence in the normal mucosa includes subclinical and/or latent infections, and that the infection with a low number of virus copies is common in the oral cavity ${ }^{8}$.

Table 1 depicts the techniques and the results obtained by different authors as to the identification of the HPV type in the normal oral mucosa.

Human papillomavirus prevalence in benign lesions (squamous cells papilloma, condiloma acuminata, common wart and focal epithelial hyperplasia of the oral cavity and oropharynx related to the virus).

Oral and oropharynx squamous cells papilloma are benign tumors that occur mainly between 30 and 50 years of age, although they may also occur below 10 years of age ${ }^{22}$. They represent about $8 \%$ of oral tumors in children ${ }^{23}$.

They usually involve the soft palate, tongue, frenulun linguae and the lower lip. In most of the cases, the papillomas are single and small $(<1 \mathrm{~cm})^{24}$. They have an exophytic growth and show up both as a broad based ovoid bulging, or a pedicled lesion. The surface may present small finger-like projections, giving it a rough verruca contour. The color varies from white to pinkish, depending on the levels of keratinization and vascularization ${ }^{25}$.

\section{Oropharynx and oral condiloma acuminata}

Oral condiloma acuminata is usually considered a sexually transmitted disease, acquired by oral sexual contact. Currently, the trend is to consider that the oral condiloma may be acquired not only by oral Sex, but also by self inoculation or as a result of maternal transmission ${ }^{20,25,26}$.

Clinical and histological similarities between squamous cells papilloma, condiloma acuminata and verruca in the oral cavity are clear ${ }^{27}$. This differentiation with PCE is difficult and purely academic. In the mouth they are usually present as small pinkish or whitish nodules, which spread in papillary projections and may be pedicled or sessile. The surface contour, in most of the cases, is cauliflower-like rather than papillomatous ${ }^{24}$. They occur alone or in multiple form, frequently on the tongue, lip, palate and floor of the mouth ${ }^{28}$.

In the genital tract, the terms papilloma and condiloma were used separately, until the year 1970; since then, both lesions are called condiloma. This modification may also be applied to oral lesions, because both the papilloma and the condiloma have the same HPV types found in genital condilomas ${ }^{20}$.

The human papillomavirus was detected in condilomatous oral lesions, initially by immunohistochemistry, and later by hybridization techniques, with a positiveness varying between $75 \%$ to $85 \%$ for HPV 6 and $11^{20,24}$.

In 1991, Zeuss et al. ${ }^{29}$, considered HPV 6 and 11 as being the types most frequently associated to benign papillomatous oral lesions.

\section{Oral and oropharynx common wart}

The common wart is one of the most common skin lesions, specially in children ${ }^{24}$. They are clinically undistinguished from PCE and condiloma, appearing as a sessile papillomatous whitish lesion of rough surface ${ }^{25}$. They are frequently located on the lips, hard palate, gums and tongue dorsum ${ }^{30}$. The diagnosis of an oral wart must be restricted to a lesion with clinical and histological characteristics of a common skin wart, and confirmed by seeing the HPV types in the skin wart ${ }^{20}$.

Many authors showed the presence of the virus in oral warts by immunohistochemistry and hybridization 
Table 1. Results from various authors as to HPV identification in the normal oral mucosa.

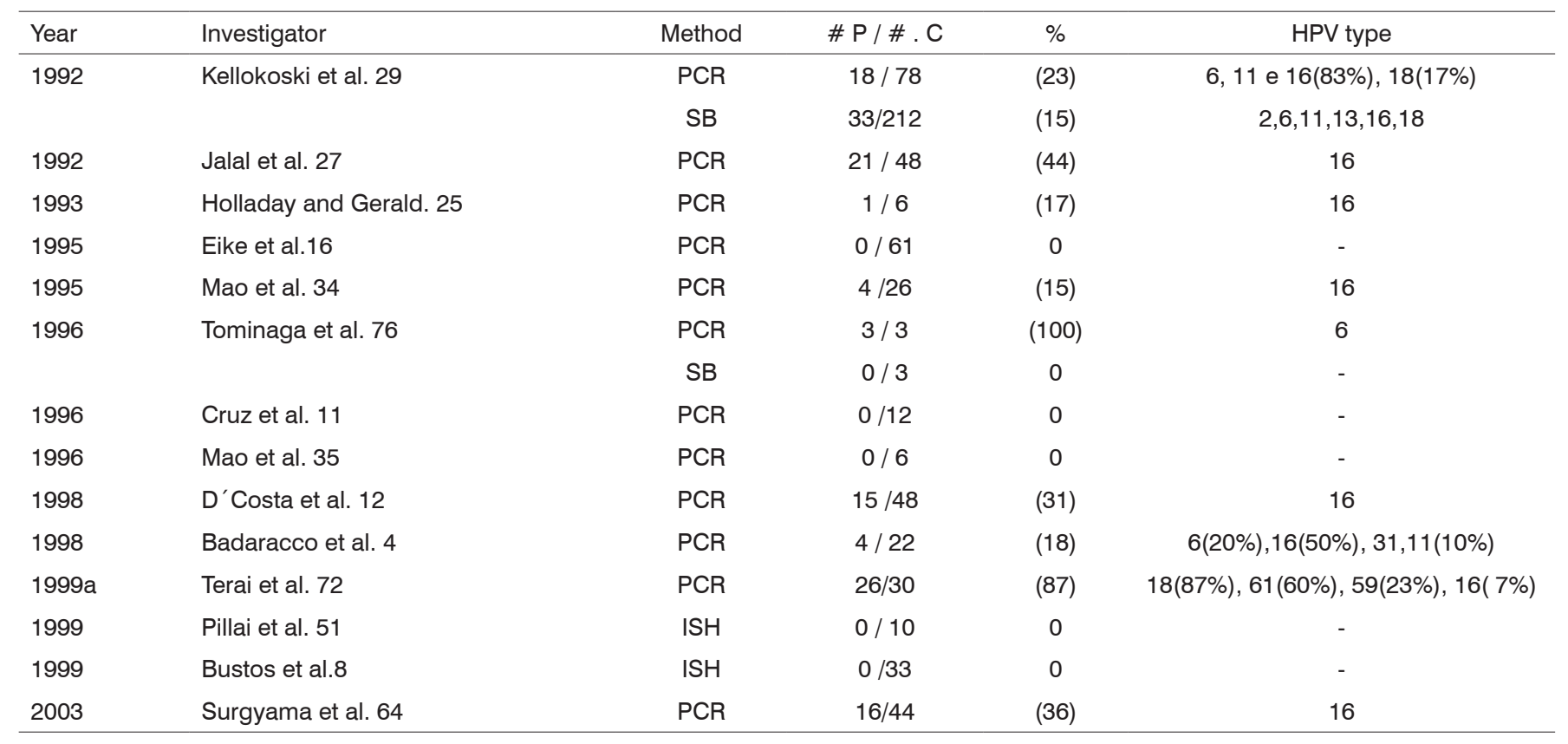

\# = number; $\mathrm{P}=$ positives; $\mathrm{C}=$ cases; $\mathrm{ISH}=$ in situ hybridization; $\mathrm{SB}=$ Southern blot hybridization; $\mathrm{PCR}=$ polymerase chain reaction.

tests. They observed a variation in the HPV detection rates from $43 \%$ to $100 \%$ in oral warts ${ }^{29,31,32}$.

HPV prevalence in oral warts seems to be HPV 2, followed by the HPV 57, although more studies are necessary to identify the broad spectrum oral infectiosn caused by skin HPV types ${ }^{20,33}$.

Table 2 shows the techniques and the results of the studies about papillomas, condilomas and warts in the oral cavity and oropharynx.

\section{Oral focal epithelial hyperplasia (FEH)}

The term focal epithelial hyperplasia (FEH), or Heck's disease, introduced by Archard et al. ${ }^{34}$ in 1965, to describe multiple nodular elevations in the oral mucosa observed in Alaska Eskimos and North and South American Indians. It is rarely observed in caucasians $\mathrm{s}^{35}$. It has also been described in Israel, South Africa and Sweeden ${ }^{36}$.

It is a benign lesion that may be located in the oral mucosa, lips and tongue, and most notably in the lower $\operatorname{lip}^{24,37,38}$. It is clinically characterized by multiple painless and soft papules, of color that varies between pale pink and the normal mucosal color. A strong family history has been suggested by a number of authors ${ }^{24,25,50}$.

Viral etiology has been initially shown by immunohistochemistry and later on by hybridization techniques identifying HPV 13 and 32, which were detected in 75$100 \%$ of the cases $^{32}$.

HPV 13 and 32 were considered specific in focal epithelial hyperplasia, however, HPV 32 was also found in other oral lesions, but never outside the oral cavity ${ }^{36,39,40}$. The studies and their results are depicted on table 3.

\section{Human papillomavirus prevalence in oral cancer and oropharynx}

Unfortunately, oral cancer still bears high mortality rates. Its incidence rate varies from one region to another, being high in India, Sri Lanka, Vietnam, Filipinas, Hong Kong and Taiwan, where about $30 \%$ of all the cancers occur in the oropharynx. India has approximately 56,000 new cases per year, and is probably among the highest incidence rates in the world ${ }^{41}$

It is a disease that affects patients in their 50th decade of life, being more evident between 60 and 70 years of age. Oral cancer includes malignant neoplasms in the lips, oral cavity and oropharyn $x^{42}$. Oral cancer is a severe and growing public health concern in Brazil, corresponding to $4 \%$ of all cancer types, occupying the eighth place among the tumors that affect men, and the 11th among women ${ }^{43}$.

The most common location for oropharynx cancers, is the palatine tonsils. Notwithstanding, lingual cancer corresponds to $30 \%$ of these ${ }^{44}$. About $90 \%$ of these lesions are located in soft tissues and are originated from squamous epithelium ${ }^{20}$

Cigarette smoking and alcohol are the main causes of oral cancer. They act in synergy and are a dosedependent ${ }^{12,17}$. However, part of the population develops 
Table 2. Results from various studies as to HPV identification in papillomas (including condiloma and wart) in the oral cavity and oropharynx.

\begin{tabular}{|c|c|c|c|c|c|c|}
\hline Year & Investigator & Lesion & Method & \#.P / \#. C & $\%$ & HPV type \\
\hline \multirow[t]{2}{*}{1986} & Adler-Storthz et al. ${ }^{78}$ & Verruga & $\mathrm{IHQ}$ & $6 / 11$ & (55) & HPV + \\
\hline & & & ISH & $6 / 11$ & (55) & 2 (83\%), 4 (17\%) \\
\hline 1986 & & & $\mathrm{IHQ}$ & $4 / 7$ & $(57)$ & HPV + \\
\hline 1986 & Syrjänen. ${ }^{68}$ & Condiloma & ISH & $2 / 2$ & $(100)$ & $6(50 \%)$ e $11(50 \%)$ \\
\hline \multirow[t]{2}{*}{1987} & Eversole et al. ${ }^{18}$ & Condiloma & $\mathrm{IHQ}$ & $5 / 20$ & $(25)$ & $\mathrm{HPV}+$ \\
\hline & & & ISH & $18 / 20$ & $(90)$ & 6, $11(85 \%), 2(5 \%)$ \\
\hline 1991 & Zeuss et al..$^{81}$ & Papiloma & ISH & $4 / 30$ & (13) & 6 e 11 \\
\hline \multirow[t]{2}{*}{1991} & Zeuss et al. ${ }^{81}$ & Condiloma & ISH & $15 / 15$ & $(100)$ & 6 e 11 \\
\hline & & & $\mathrm{ISH}$ & $11 / 15$ & (73) & $6,11,16,18,31,33,35$ \\
\hline \multirow[t]{2}{*}{1994} & Padayachee et al. ${ }^{46}$ & Verruga & $\mathrm{IHQ}$ & $12 / 21$ & $(57)$ & $\mathrm{HPV}+$ \\
\hline & & & ISH & $15 / 21$ & $(71)$ & 2 e 57 (87\%), 2 (13\%) \\
\hline \multirow[t]{3}{*}{1995} & Padayachee et al. ${ }^{47}$ & Verruga & $\mathrm{ISH}$ & $14 / 19$ & (74) & 2 \\
\hline & & & ISH & $12 / 19$ & $(63.5)$ & 57 \\
\hline & & & PCR & $8 / 19$ & $(43)$ & 2,57 \\
\hline 1996 & Tominaga et al. ${ }^{76}$ & Condiloma & PCR & $1 / 8$ & (13) & 6 \\
\hline 1998 & Bishop et al. ${ }^{6}$ & Condiloma & ISH & $1 / 1$ & $(100)$ & 6 e 11 \\
\hline 1998 & Badaraccoe & Condiloma & PCR & $7 / 7$ & $(100)$ & $6,31,57,56,44,16$ \\
\hline
\end{tabular}

\# = number; $\mathrm{P}=$ positives; $\mathrm{C}=$ cases; IHQ = immunohistochemistry; ISH = in situ hybridization; $\mathrm{SB}=$ Southern blot hybridization; $\mathrm{PCR}=$ polymerase chain reaction; HPV+ = positive human papillomavirus.

Table 3. Results from various authors as to HPV identification in the oral cavity and oropharynx focal epithelial hyperplasia.

\begin{tabular}{|c|c|c|c|c|c|}
\hline Year & Investigator & Method & $\# . P / \# . C$ & $\%$ & HPV type \\
\hline 1984 & Syrjänen ${ }^{27}$ & $\mathrm{IHQ}$ & $1 / 1$ & $(100)$ & $\mathrm{HPV}+$ \\
\hline 1987 & Hernandez-Jauregui et al. ${ }^{35}$ & SB & $7 / 7$ & $(100)$ & 13 \\
\hline 1989 & Garlick et al. ${ }^{37}$ & SB & $4 / 4$ & $(100)$ & 13(75\%), 32(25\%) \\
\hline 1989 & Henke et al. ${ }^{38}$ & $\mathrm{ISH}$ & $16 / 17$ & (95) & 13(59\%), 32(35\%) \\
\hline \multirow[t]{3}{*}{1991} & Padayachee \& Van Wyk ${ }^{36}$ & $\mathrm{IHQ}$ & $7 / 18$ & (39) & $\mathrm{HPV}+$ \\
\hline & & ISH & $15 / 18$ & (83) & $32(60 \%), 13(33 \%)$ \\
\hline & & & & & $11(7 \%)$ \\
\hline 2002 & Schwenger et al. ${ }^{76}$ & PCR & $5 / 5$ & $(100)$ & $13(20 \%)$ e $32(60 \%)$ \\
\hline
\end{tabular}

$\#=$ number; $\mathrm{P}=$ positives; $\mathrm{C}=$ cases; IHQ = immunohistochemistry; ISH = in situ hybridization; $\mathrm{SB}=\mathrm{Southern}$ blot hybridization; $\mathrm{PCR}=$ polymerase chain reaction; HPV + = positive human papillomavirus. 
Table 4. Results from various authors as to HPV identification in oral carcinoma.

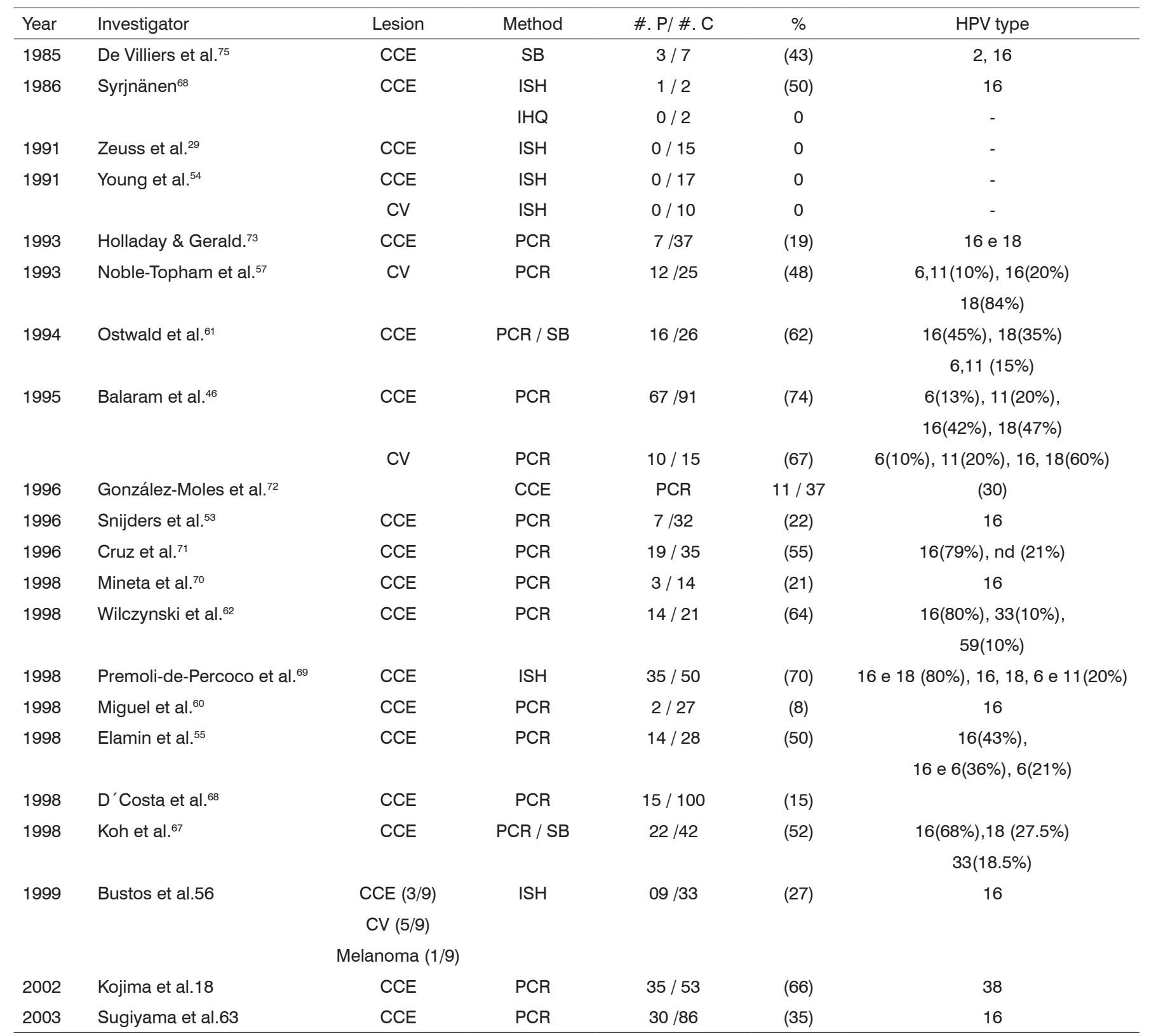

\# = number; $\mathrm{P}=$ positives; $\mathrm{C}=$ cases; IHQ = immunohistochemistry; ISH = in situ hybridization; $\mathrm{SB}=$ Southern blot hybridization; PCR = polymerase chain reaction; $\mathrm{nd}=$ undetermined; $\mathrm{CV}=$ verrucous carcinoma; $\mathrm{CCE}=$ squamous cell carcinoma.

oral cancer without having been exposed to these risk factors, suggesting other causes, such as: genetic predisposition, diet and viral agents, most specifically HPV 345 .

The simultaneous presence of chemical agents and HPV infection in the oral mucosa may favor the malignant transformation ${ }^{46}$. Notwithstanding, the HPV role as an etiological agent in the oral cancer is less than that from alcohol and tobacco use because HPV infection prevalence is less than alcohol and tobacco use in the genesis of oral cancer ${ }^{20,47}$.

Syrjänen et al. ${ }^{48}$, in 1983, suggested that HPV may be involved in oral cavity squamous cell carcinoma, when they described HPV cytopathological alteration in oral cancer, identical to those previously found in uterine cervix cancer, although we still lack proof by other DNA hybridization methods.

Many studies have shown HPV 16 to be the most prevalent type in oral cancer, as it happens in anogenital 
cancer $^{24,25,49}$.

In a 2001 metanalysis, Miller \& Johnstone ${ }^{47}$, showed an HPV increase in oral epithelial carcinoma and dysplasias when compared to the normal oral mucosa, mainly in high risk genotypes. Results show HPV to be an independent risk factor for squamous cell oral carcinoma. In 2003, Herrero et al. ${ }^{50}$, studied HPV in oral cancer and observed a higher prevalence of HPV 16 in the oral cavity and the oropharynx among patients that had more than one sex partner and/or who practiced oral sex, while the lowest prevalence was seen among smokers.

According to many studies, the HPV prevalence rate in oral cancer varied from $0-100 \% 0^{17,25,29,51-54}$. This broad variation in HPV detection rate is explained by the different detection methods used in the HPV investigation ${ }^{25}$.

One of the greatest difficulties in identifying HPV in oral cancer patients is the presence of this virus in only one subpopulation of cells and the reduced number of copies of these cells which are infected. That is why we need high sensitivity detection methods ${ }^{55}$.

\section{Verrucous carcinoma}

The verrucous carcinoma was first described as a variant of the squamous cells carcinoma, which originates in the oral cavity.

Also known as Ackerman's tumor, its growth is exophytic, slow and invasive -only superficially, with a low metastasis rate, and it may be treated with simple excision. Many authors have reported the HPV presence in the verrucous carcinoma $a^{20,32,46,56-58}$.

\section{Squamous cells carcinoma (SCC)}

Encompasses about $95 \%$ of all the oral cancers. Its clinical aspects vary from a nodule up to a chronic ulcer. Many researchers have shown HPV present in SCC ${ }^{18,59-62}$. Initially we did microscopy, immunohistochemistry and, more recently, molecular biology tests ${ }^{20}$.

Studies have shown the important role of HPV in head and neck cancers, and also suggest that HPV 16 may be involved in the development of some oral carcinomas ${ }^{56,60,63}$

Table 4 shows oral carcinoma studies with their results and techniques.

\section{MATERIALS AND METHODS}

We searched the MEDLINE database and textbooks, English and Portuguese medical literature, from January 1990 to December 2003, and found reports of HPV prevalence by virus detection methods (immunohistochemistry and molecular biology exams) in the normal oral mucosa, in virus-related benign lesions (squamous cells papilloma, condiloma, verruca and focal epithelial hyperplasia) and in oral cancer.

In the MEDLINE database, we used the follow- ing keywords: detection, human papillomavirus oral, Polymerase Chain Reaction, human papillomavirus, oral cavity, normal oral cavity, oral lesions, papillary lesions, oral condiloma acuminata, oral warts, oral focal epithelial hyperplasia, oral cancer, squamous cell carcinomas, among others, they were used alone or in combination in the search.

After we selected these scientific papers we included some relevant papers about oral HPV, published before the period established in the search string.

\section{DISCUSSION}

HPV prevalence in the oral cavity and oropharynx is considered uncertain, because many studies have shown different results with the estimate of a small number of patients, and a modest identification among the different types of HPV found in mucosal lesions ${ }^{17}$.

HPV diagnosis in the oral mucosa and the oropharynx may be suspected by the clinical exam of the lesion, cytology and biopsy; however the molecular biology exams are the ones able to detect the HPV DNA in the cell, stressing the polymerase chain reaction as the most sensitive method to detect HPV. Notwithstanding, the assessment of different methods used to detect HPV16 is important and fundamental in order to establish the etiological role of HPV in oral lesions.

Table 1 shows HPV 16 prevalence in the normal oral mucosa in 16 results from 14 authors, by the SB, ISH and PCR detection methods, making up 56\% of all the results, and this seems to depend on the population examined and the choice of method used to detect HPV ${ }^{21,16}$.

Still table 1 shows 6 negative results obtained by the ISH, SB and PCR detection methods, which make up $40 \%$ of the total number of results investigated.

It is probably due to the small number of samples used in the research and the very difficulty in detecting $\mathrm{HPV}$ in swabs and biopsy samples.

Among the factors that generate controversy about HPV prevalence in the normal oral mucosa seen on Table 1, we can stress the large variation in HPV detection rates, from $0 \%$ to $100 \%$ despite the use of more sensitive methods -such as PCR; another factor is the relationship between results and sample sizes, which varied in 3 samples, with $100 \%$ positiveness for HPV in the Tominaga et al. ${ }^{64}$ study from 1996, reaching up to 212 samples with 15\% of HPV detection in the Kellokoski et al. ${ }^{65}$ study from 1992, thus showing a great difference between the results, which is probably due to a failure in the HPV detection methods or in harvesting the material or, even, because we do not know the exact HPV infection pathway in the normal oral mucosa $\mathrm{a}^{32,13,16}$.

The human papillomavirus infection in oral cavity and oropharynx benign lesions (squamous cell papilloma, condilomas and verruca) in 25 results from 14 authors was 
of HPV 6 and 11, in papillomas and in condilomas, through the following methods: IHQ, ISH and PCR; in oral warts, the prevalence was of 2 and 57, by the IHQ, ISH, HSB and PCR methods, with HPV 2 dominance. The presence of HPV is clear in all cases, varying from $13 \%$ to $100 \%$ in positiveness, with its prevalent types, according to the lesion, regardless of the methods used. It is very likely that this happens because these lesions bear a larger number of cells with HPV DNA. We could also see a dominance of low risk HPV, specially HPV 6 and 11 justified because they are the types most frequently associated with oral benign papillomatosis lesions ${ }^{29}$, whilst the high risk ones, like the HPV 16, only showed up in 3 results.

Table 3 depicts HPV prevalence in oral focal epithelial hyperplasia in 7 results from 6 authors and it was HPV 13 and 32, through the many detection methods: IHQ, ISH, HSB and PCR, with a variation in HPV detection rates of $39 \%$ to $100 \%$. We could also see that all results were HPV positive and in 2 cases the HPV was not typed, justified by the IHQ technique, what makes HPV evident in this disease.

Table 4 depicts a variation in HPV detection rates, from $0 \%$ to $74 \%$ in 24 results of oral cancer from 21 authors: it is probably due to the different detection methods bearing different sensitivity and sample sizes used in the research, from 2 to 100 samples. Another factor is the difficulty in detecting HPV in oral cancer, due to the presence of such virus in only one subpopulation of cells and the low number of copies found in infected cells ${ }^{55}$.

Still in Table 4, we see a high HPV 16 prevalence through the ISH, HSB and PCR techniques, being present in $80 \%$ of all the results. HPV 16 rates detected varied in $8 \%$, in other words, 2 positive results from the 27 samples in the Wilczynski et al. ${ }^{62}$ (1998) study, and this suggests a huge discrepancy among the results. We could also see 4 negative results for HPV by the IHQ and ISH methods, which is probably due to the low sensitivity of these methods when compared to PCR and the small sample size. Therefore, we still require more studies using different HPV detection methods to better confirm the virus presence in oral cancer.

HPV 16 presence in oral cancer in many studies depicted in Table 4 does not prove that the virus be indeed responsible for the disease, notwithstanding, it does prove that it may contribute to the incidence of oral cancer, specially among non-smokers and non-alcoholics ${ }^{3,45}$, or even in the simultaneous presence of chemical agents and HPV infection, which may lead to malignant transformation.

Other factors that contribute to increase HPV prevalence in the oral cavity and oropharynx are: a reduction in the patient's immune response for the virus ${ }^{66}$, having more than one sexual partner and the practice of oral sex ${ }^{50}$ - these all increase the likelihood of an HPV infection and its recurrence.
HPV 16 prevalence found in the oral cancer results (Table 4) and the normal oral mucosa (Table 1) suggests that HPV 16 is the one most prevalent in the oral mucosa and oropharynx. Comparing HPV prevalence between tables 1 and 4 could value the HPV relationship in the genesis of certain dysplasia. Notwithstanding, the results seen in the tables bring about controversies, which are attributed, mainly to the sensitivity variation of the methods employed, as well as the diversity of the populations studied and the sample sizes.

\section{CONCLUSION}

The literature analysis on the HPV prevalence in the oral cavity and oropharynx leads us to the following conclusions:

1. Among the techniques used to diagnose HPV, the most sensitive is PCR;

2. HPV prevalence in the normal oral mucosa presents discrepant results;

3. HPV prevalence in virus-related benign lesions is confirmed;

4. Despite HPV prevalence in oral cancer there still are controversies as to the virus presence and oral carcinogenesis;

5. Thus, more studies are necessary in order to enhance the methods used to detect HPV DNA and the sample collection techniques (swabs or biopsies), aiming at having less result interference and greater clarifications about HPV infection and its prevalence in both the oral cavity and the oropharynx, and we are motivated to continue the HPV research, especially in the normal oral mucosa and in oral cancer.

\section{REFERENCES}

1. Perez M, Gil AO, Wroclawski ER, Guidi HG, Schiavini JL, Carvalho JJ. HPV no homem. In: Carvalho JJM, Oyakawa N. I Consenso Brasileiro do HPV, 1a edição, São Paulo: BG Cultural; 2000. 4: 7-16.

2. Alvarenga GC, Sá EM, Passos MR, Pinheiro VM. Papilomavírus Humano e carcinogênese no colo do útero. J Bras Doenças Sex Transm 2000; 12(1): 28-38.

3. Bouda M, Gorgoulis VG, Kastrinakis NG, Giannoudis A, Tsoli E, Danassi-Afentaki D et al. "High risk" HPV types are frequently detected in potentially malignant and malignant oral lesions, but not in normal oral mucosa. Mod Pathol 2000;13(6): 644-53.

4. Camargos AF e Hugo de Melo V. Doenças sexualmente transmissíveis. In: Camargos AF e Hugo de Melo V. Ginecologia ambulatorial, $1^{\text {a }}$ edição, Belo Horizonte: editora Coopamed; 2001. 38: 397-400.

5. Tavares R, Passos M, Cavalcanti S, Pinheiro V, Rubinstein I. Condiloma genital em homens e soropositividade para HIV. DST. J. Bras. Doenças sexualmente transmissíveis. 2000; 12(1): p.4-27.

6. Pfister WH. Papilomavírus em patologia humana: epidemiologia, patogênese e papel oncogênico. In Gross GE, Barrasso R. Infecção por papilomavírus humano: Atlas clínico de HPV. Porto Alegre: Ed. Artes Médicas; 1999. 1: 01-18

7. Okada MMK, Gonçalves MAG, Giraldo PC. Epidemiologia e Patogênese do Papilomavírus humano (HPV). In: I Consenço Brasileiro de HPV, n²1, São Paulo: BG Editora; 2000. 1; p. 01-06.

8. Oliveira MC, Soares RC, Pinto PL, Costa ALL. HPV e carcinogênese 
oral: revisão bibliográfica. Rev Bras Otorrinolaringol 2003; 69(4): 553-9.

9. Lancellotti CLP, Levi JE, Silva MALG, Schwarzschild M, Nicolau SM Diagnóstico laboratorial. In: Carvalho JJM, Oyakawa N. I Consenso Brasileiro do HPV, 1a edição, São Paulo: BG Cultural; 2000. 4: 4560.

10. Zahm DM, Nindl I, Schneider A. Princípios gerais do diagnóstico: detecção do papilomavírus humano. In Gross GE, Barrasso R. Infecção por papilomavírus humano: Atlas clínico.

11. De Villiers EM. Human Pathogenic Papillomavirus Types: an update Curr Top Microbiol Immunol 1994; 186: 1-12.

12. Miller CS, White DK, Ky L. Human papillomavirus in oral mucosa, premalignant conditions, and squamous cell carcinoma: A retrospective review of the literature. Oral Sug Oral Med Oral Pathol Oral Radiol Endod. 1996; 82(1): 57-68.

13. Sousa TRB. Papilomavírus humano e a detecção do DNA viral no carcinoma epidermóide da cavidade oral: revisão da literatura. São Paulo, 2001. (Tese de Mestrado - Faculdade de Ciências Médicas da Santa Casa de São Paulo).

14. Ribeiro KMX. Estudo da ocorrência do Papilomavírus humano em tonsilas palatinas na população pediátrica. São Paulo, 2002, p. 01-39 (tese de mestrado - Escola Paulista de Medicina).

15. Gravitt PE, Peyton CL, Alessi TQ, Wheeler CM, Coutlee F, Hildesheim A. Improved Amplification of Genital Human Papillomaviruses. J of Clinical Microbiology 2000; 357-61.

16. Terai M \& Takagi M. Human Papillomavirus in Oral Cavity. Oral Med Pathol 2001; 6: 1-12.

17. Smith EM, Hoffman HT, Summersgill KS, Kirchner HL, Turek LP Haugen TH. Human Papillomavirus and Risk of Oral Cancer. Laryngoscope 1998; 108: 1098-103.

18. Kojima A, Maeda H, Sugita Y, Tanaka S, Kameyama. Human papillomavirus type 38 infection in oral squamous cell carcinomas. Oral Oncology 2002; 38: 591-6.

19. Terai M \& Burk R. Complete Nucleotide Sequence and Analysis of a Novel Human Papillomavirus (HPV 84) Genome Cloned by an Overlapping PCR Method. Virology 2001; 279: 109-15.

20. Syrjänen S. Human papillomavirus infections and oral tumors. Med Microbiol Immunol 2003; 192: 123-8.

21. Terai M, Haschimoto K,Yoda K, Sata T. High prevalence of human papillomaviruses in the normal oral cavity of adults. Oral Microbiol Immunol 1999a; 14: 201-5.

22. Scully C, Prime S, Maitland N. Papillomaviruses: their possible role in oral disease. Oral Surg Oral Med Oral Pathol 1985; 60: 166-74.

23. Pignatari SS, Weekx LL, Bordasch A. Biologia Molecular no Diagnóstico das Infecções por Papilomavirus Humano (HPV) em Otorrinolaringologia. Rev Bras De Otorrinolaringologia 1995; 61(2): 91-5.

24. Chang F, Syrjãnen S, Kellokoski J, Syrjãnen K. Human papillomavirus (HPV) infections and their associations with oral disease. J Oral Pathol Med 1991; 20: 305-17.

25. Syrjänen S. Cavidade oral e trato respiratório superior: diagnóstico e tratamento. In: Gross GE, Barrasso R. Infecção por papilomavírus humano: Atlas clínico de HPV, 2o Edição. Porto Alegre: Editora Artes Médicas Sul Ltda. 1999. 12: 399-409.

26. Zur Hausen H. Papillomavirus infections - a major cause of human cancers. Bochimica et Acta. 1996; 1288: 55-78.

27. Syrjänen S, Syrjänen K, Ikenberg H, Gissmann L, Lamberg M. A human papillomavirus closly related to HPV 13 found in a focal epithelial hyperplasia lesion (heck disease). Arch Dermatol Res 1984; 276 199-200.

28. Suskind DL, Mirza N, Risin D, Stanton D, Sachdeva R. Codyloma Acuminatum Presenting as a Base of tongue mass. Otolaryngology Head and Neck Surgery, 1996; 114 (3): 487-90.

29. Zeuss MS, Miller CS, Wite DK. In situ hybridization analysis of human papillomavirus DNA in oral mucosal lesions. Oral Surg Oral Med Oral Pathol 1991; 71: 714-20.

30. Nassif Filho AC, Boros LF, Júnior JB. Infecção da cavidade oral pelo papilomavírus humano. In Campos CA e Costa HO. In: Tratado de otorrinolaringologia (SBORL), 1aㅡ edição, São Paulo: Ed. Roca; 2003.
3(34): 314-16

31. Padayachee A. Human papilomavirus (HPV) types 2 and 57 in oral verrucae demonstrated by in situ hybridization. J Oral Pathol Med 1994; 23: 413-7.

32. Praetorius F. HPV - Associated diseases of oral mucosa. Clin dermatol 1997; 15(3): 399-413.

33. Padayachee A, Sanders CM, Maitland NJ. A polumerase chain reaction (PCR) investigtion of oral verrucae which contain HPV types 2 and 57 by in situ hybridization. J Oral Pathol Med 1995; 24: 329-34.

34. Archard HO, Heck JW, Standly HR, Gallup NM. Focal epithelial hyperplasia: an unusual oral mucosal lesion found in Indian children. Oral Surg 1965; 20: 201-12.

35. Hernandez-Jaurequi P, Eriksson A, Perez RT et al. Human papillomavirus type 13 DNA in focal epithelial hyperplasia among Mexicans. Arch Virol 1987; 93: 131-7.

36. Padayachee A \& Van Wyk CW. Human papillomavirus (HPV) DNA in focal epithelial hyperplasia by in situ hybridization. J Oral Pathol Med 1991; 20: 210-4.

37. Garlick JÁ, Calderon S, Buchner A, Mitrani-Rosenbaum S. Detection of human papillomavirus in focal epithelial hyperplasia. J Oral Pathol Med 1989; 18: 172-7.

38. Henke R-P, Guèrin-Reverchon I, Milde-Langosch K, Strömme-Koppang $H$, Löning $T$. In situ detection of human papillomavirus Types 13 and 32 in focal epithelial hyperplasia of the oral mucosa. J Oral Pathol Med 1989; 18: 419-21.

39. De Villiers EM. Heterogeneity of the human papilomavirus group. J Virol 1989; 63(11): 4898-903.

40. Kellokoski JK, Syrjänen SM, Kataja V,Yliskoski M, Syrjânen KJ. Acetwhite staining and its significance in diagnosis of oral mucosa lesions in women with genital HPV infections. J Oral Pathol Med 1990; 19: 278-83.

41. Pillai MR, Phanidhara A, Kesari Al, Nair P, Nair MK. Cellular Manifestations of Human Papillomavirus Infection in the Oral Mucosa. Journal of Surgical Oncology 1999; 71: 10-15.

42. Llewellyn CD, Johnson NW, Warnakulasuriya KAAS. Isk factors for squamous cell carcinoma of the oral cavity in young people - a comprehensive literature review. Oral Oncology 2001; 37: 401-18.

43. Soares PC, Malavazi I, Reis RI, Neves KA, Zuanon JAS, Neto CB, et al. Presença do papilomavírus humano em lesões malignas de mucosa oral. Revista da Sociedade Brasileira de Medicina Tropical. 2002, 35(5): 439-44

44. Spitz MR. Epidemiology and Risk Factors for Herd and Neck cancer. Seminars in Oncology 1994; 21: 281-8.

45. Scully C. Oral squamous cell carcinoma; from an hypothesis about a virus, to concern about possible sexual transmission. Oral Oncology 2002; 38: 227-33

46. Balaram P, Nalinakumari KR, Abraham E, Balan A, Hareendran NK Bernard HU, et al. Human papillomaviruses in 91 oral cancers from Indian betel quid chewers - high prevalence and multiplicity of infections. Int J Cancer 1995; 61: 450-4.

47. Miller CS \& Johnstone BM. Human Papillomavirus as a risk factor for oral squamous cell carcinoma: a meta-analysis, 1982-1997. Oral Sug Oral Med Oral Pathol Oral radiol Endod 2001; 91(6): 622-35.

48. Syrjänen K, Syrgänen S, Lamberg M, Pyrhönen S and Nuutinen J. Morphological and immunohistochemical evidence suggesting human papillomavirus (HPV) involvent in oral squqmous cell carcinogenesis Int. J. Oral Surg 1983; 12: 418-24.

49. IARC. IARC Monographs on the evaluation of carcinogenic risks to humans.Vol. 64, Human papillomaviruses. Lyon 1995. p. 114-7.

50. Herrero R, Castellangue X, Pawlita M, Lissowska J, Kee F, Balaram P. Human papillomavirus and oral cancer: the international Agency for Research on cancer Multicenter Study. J Natl Cancer Int 2003 95(23): 1772-83.

51. Eike A, Buchwald C, Rolighed J. Human papillomavirus (HPV) is rarely present in normal oral and nasal mucosa. Clin Otolaryngo 1995; 20: 171-3

52. Mao E-J. Prevalence of human papillomavirus 16 and nucleolar organizer region counts in oral exfoliated cells from normal and malignant 
epithelia. Oral Surg Oral Med Oral Pathol Oral Radiol Endod. 1995; 80: 320-9.

53. Snijders PJF, Scholes AGM, Hart CA, Jones AS, Vaughan ED, Woolgar JA, Meijer CJLM, Walboomers JMM, Field JK. Prevalence of mucosotropic human papillomaviruses in squamous-cell carcinomas of the head and neck. Int J Cancer 1996; 66: 464-9.

54. Young SK, Min KW. In situ DNA hybridization analysis of oral papillomas, leukoplakias, and carcinomas for human papillomavirus. Oral Surg Oral Med Oral Pathol 1991; 71:726-9.

55. Elamin F, Steingrimsdottir S, Wanakulasuriya N, Johnson N, Tavassoli M. Prevalence of human papillomavirus infection in premalignant and malignant lesions of the oral cavity in U.K. subjects: a novel method of detection. Oral Oncology 1998; 34: 191-7.

56. Pavan JV et al. Detection Del vírus papiloma humano em lesiones cancerosas orales em la ciudad de Córdoba. Rev Fac Cienc Méd Córdoba 1999; 56(1): 65-71.

57. Noble-Topham SE, Fliss DM, Hartwick WJ, McLachlin CM, Freeman JL, Noyek AM. Detection and typing of human papillomavirus in verrucous carcinoma of the oral cavity using the polymerase chain reaction. Arch Otolaryngol Head Neck Surg 1993; 119: 1299-304.

58. Sarruf MBJ, Dias EP. Avaliação Citopatológica da cavidade bucal em pacientes portadores de infecção genital pelo Papilomavírus Humano (HPV). J Bras Doenças Sex Trans 1997; 9(2): 4-18.

59. Mao E-J, Schwartz SM, Daling JR, Oda D, Tickman L, Beckmann AM. Human papilloma viruses and $\mathrm{p} 53$ mutations in normal pre-malignant and malignant oral epithelia. Int J Cancer 1996; 69: 152-8.

60. Miguel RE, Villa LL, Cordeiro AC, Prado JC, Sobrinho JS, Kowalski LP. Low prevalence of human papillomavirus in a geographic region with a high incidence of head and neck cancer. Am J Surg 1998; 176(5): 428-9.

61. Ostwald C, Müller P, Barten M, Rutsatz K, Sonnenburg M, Milde-Langosch K, Löning T. Human papillomavirus DNA in oral squamous cell carcinomas and normal mucosa. J Oral Pathol Med 1994; 23: 220-5.

62. Wilczynski SP, Lin Bty, Xie Y, Paz IB. Detection of Human Papillomavirus DNA and Oncoprotein Overexpression Are Associated with Distinct Morphological Patterns of Tonsillar Squamous Cell Carcinoma. American J of Pathology 1998; 152(1): 145-56.

63. Sugiyama M, Bhawal UK, Dohmen T, Shigehiro O, et al. Detection of papillomavirus- 16 and HPV-18 DNA in normal, dysplastic, and malignant oral epithelium. Oral Surg Oral Med Oral pathol Oral Radiol Oral Endod May 2003; 95(5): 594-600.

64. Tominaga T, Fukushima K, Nishizaki K, Watanabe S, Masuda Y, Ogura H. Presence of Human Papillomavirus Type of in Tonsillar Codyloma Acuminatum and Clinically Normal Tonsillar mucosa. Jpn J Clin Oncology 1996; 26: 393-7.

65. Kellokoski JK, Syrjänen SM,Chang F, Yliskoski M, Syrjänen KJ: Southern blot hybridization and PCR in detection of oral human papilomavirus (HPV) infections in women with genital HPV infections. J Oral Pathol Med 1992; 21: 459-64.

66. Bishop JW, Emanuel JM, SimsKL. Disseminated Mucosal Papilloma/ Condyloma Secundary to Human Papillomavirus - The American journal of Pathology 1998; 22(10): 1291-5.
67. Koh JK, Cho NP, Kong G, Lee JD, Yoon K. p53 mutations and human papillomavirus DNA in oral squamous cell carcinoma: correlation with apoptosis. Br J Cancer 1998; 78: 354-9.

68. D’Costa J, Sarannath D, Dedhia P, Sanghvi V, Mehta AR. Detection of HPV-16genome in human oral cancers and poentially malignant lesions from India. Oral Oncol 1998; 34: 413-20.

69. Primoli-De-Percoco G, Ramirez JL, Galindo I. Correlation between HPV types associated with oral squamous cell carcinoma and cervicovaginal cytology. Oral Surg Oral Med Oral Pathol 1998; 86: $77-$ 81.

70. Mineta H, Ogino T, Amano HM, Ohkawa Y, Araki K, Takebayashi S, et al. Human papilomavirus (HPV) type 16 and 18 detected in head and neck squamous cell carcinoma. Anticancer Res 1998; 18(6b): 4765-8.

71. Cruz IB, Snijders PJ, Steenbergen RD, Meijer CJ, Snow GB, Walboomers JM, et al. Age-dependence of human papillomavirus DNA presence in oral squamous cell carcinomas. Eur J Cancer B Oral Oncol 1996 32B: $5-62$

72. González-Moles MA et al. Presencia de secuencias de papilomavirus humanos 16 en los carcinomas orales de células escamosas. Medicina Oral 1996; 1: 79-84.

73. Holladay EB, Gerald WL. Viral gene detection in oral neoplasms using the polymerase chain reaction. Am J Clin Pathol 1993; 100(1): 36-40.

74. Syrjänen SM, Syrjänen KJ, Lamberg MA. Detection of papillomavirus DNA in oral mucosal lesions using in situ DNA-hybridization applied on paraffin sections. Oral Surg Oral Med. Oral Pathol. 1986; 62: 6607.

75. De Villiers EM, Weidauer H, Otto H, Zur Hausen H. Papillomavirus DNA in tongue carcinomas. Int J cancer 1985; 36: 575-8.

76. Schwenger JU, Von Buchwald C, Lindeberg H. Oral focal epithelial hyperplasia. Any risk of confusion with oral condylomas? Ugeskr Laeger 2002; 169(37): 4287-90.

77. Eversole LR, Laipis PJ, Merrell P, Choi E. Demonstration of human papillomavirus DNA in oral condiloma acuminatum. J Oral Pathol 1987; 16: 266-72.

78. Adler-Storthz K, Newland JR, Tessin BA, Yeudall WA, Shillitoe EJ Identification of human papillomavirus types in oral verruca vulgaris. J Oral Pathol 1986: 15: 230-3.

79. Badaracco G, Venuti A, Di Lonardo A, Scambia G, Mozzetti S, Benedetti Panici $\mathrm{P}$ et al. Concurrent HPV infection in oral and genital mucosa. J Oral Patho Med 1998; 27: 130-4. Munksgaard.

80. Jalal H, Sanders CM, Prime SS, Scully C, Maitland NJ. Detection of human papilloma virus type 16 DNA in oral squames from normal young adults. J Oral Pathol Med 1992; 21: 465-70.

81. Villa LL \& Franco ELF. Epidemiologic Correlates of Cervical Neoplasia and Risk of Human Papillomavirus Infection in Asymptomatic Women in Brazil. J National Cancer Institute 1989; 81(5): 332 -40.

82. Terai M, Takagi M, Matsukura T, Sata T. Oral wart associated with human papillomavirus type 2. J Oral Pathol Med 1999b; 28: 137-40. 